\title{
Dietary variation and food selection by mayfly grazers in a subtropical mountain stream
}

\author{
Yi-Li Chuang ${ }^{1}$, Shu-Fen Yu ${ }^{1,2}$ and Hsing-Juh Lin ${ }^{1 *}$
}

\begin{abstract}
Background: The classification of functional feeding groups of aquatic insects is often misleading in tropical/ subtropical streams because their feeding habits are assumed to be the same as their temperate counterparts according to the mouthpart structure and foraging behavior. This study aimed to examine the diets and preferences of mayfly grazers (Baetis spp. and Rhithrogena ampla) in a subtropical mountain stream in the dry and wet seasons.

Results: In the stream, epilithic algal communities on insect-excluded bricks (as a grazer-excluded control) were dominated by small adnate diatoms, most likely due to the high current velocity. Both grazers preferred understory and small adnate diatoms, Achnanthes spp. and Achnanthidium pyrenaicum, in both seasons. However, the stalked diatoms Gomphonema spp. were preferred only by Baetis, but not by Rhithrogena, in the dry season when the current velocity became relatively slower. The results of pairwise tests further showed that the algal compositions on the insect-excluded bricks coincided with the diets of both grazers in the wet season but were distinct from those on the bricks in the dry season. Seasonal variations in the algal compositions of the diets of Rhithrogena and on the insect-excluded bricks were apparent, but not in the diets of Baetis.

Conclusions: The algal physiognomy was most likely attributed to the impact of the high current velocity in the stream. Our results suggest that the diet preference by mayfly grazers in the stream is potentially influenced by algal availability.
\end{abstract}

Keywords: Chesson's alpha; Diatoms; Food availability; Gut content; Mouthpart; Physiognomy

\section{Background}

Herbivory is an important factor regulating the biomass and community structure of benthic algae in streams (Feminella and Hawkins 1995; Steinman 1996). Although algal biomass can be effectively reduced by herbivores in a neotropical stream (Barbee 2005), research on the functional feeding mode of grazers in tropical and subtropical streams is still limited. Not only can they limit algal biomass, but they can also alter the physiognomy and community structure of algae, exerting strong indirect effects within food webs and on nutrient cycling (Holomuzki et al. 2010). Stream food webs rely primarily on two food sources: autochthonous primary production within the stream and allochthonous organic matter transferred to the stream as leaf litter, woody debris, and

\footnotetext{
* Correspondence: hjlin@dragon.nchu.edu.tw

1 Department of Life Sciences and Research Center for Global Change Biology, National Chung Hsing University, Taichung 40227, Taiwan Full list of author information is available at the end of the article
}

dissolved organic carbon. Autochthonous algae may be more important than allochthonous organic matters to stream consumers in tropical forested headwater streams (March and Pringle 2003). An open forest canopy can lead to autochthonous algae becoming the dominant food source for herbivores in rainforest streams (Brito et al. 2006) and tropical Asia (Salas and Dudgeon 2001; Mantel et al. 2004; Yam and Dudgeon 2005; Lin et al. 2012). Autochthonous algae are the main energy source in some shaded tropical headwater streams (Mantel et al. 2004; Lau et al. 2008; 2009; Li and Dudgeon 2008). However, few studies have examined the diets of aquatic insects in tropical/subtropical streams (Boyero et al. 2009).

Aquatic insects have been shown to influence the community structure of benthic algae in temperate streams by food selection (Hill and Knight 1987; Feminella and Resh 1991; Feminella and Hawkins 1995; Peterson et al. 1998). A mat of benthic algae generally consists of a variety of 
algal physiognomic forms (Wellnitz and Ward 1998; Holomuzki and Biggs 2006). Algae in the upper layer of the mat or the overstory are expected to be easily accessible to most aquatic insects, whereas prostrate forms in the understory can only be ingested by aquatic insects possessing mouthparts specialized for detaching these algae from the substratum (Steinman 1996). The mouthpart structure and foraging behavior of aquatic insects vary among different taxa. They most likely select food on the basis of algal size or growth form (Tall et al. 2006).

In tropical and subtropical streams, benthic fauna such as aquatic insects have been identified as an obvious knowledge gap requiring further studies (Boyero et al. 2009). This knowledge gap constrains the ability to understand grazer community in general. Consequently, the feeding habits of aquatic insects in such streams are often assigned to functional feeding groups according to the mouthpart structure and foraging behavior for the North American stream fauna (Merritt et al. 2008). However, such classification of functional feeding groups is most likely misleading for various insect taxa (Boyero et al. 2009). Several studies have investigated the effects of mayfly grazers on algae in temperate streams or in laboratory channels (Kohler 1984; Wallace and Gurtz 1986; Lamberti et al. 1987). However, relatively little attention has been paid to the feeding behavior and diet of mayfly grazers in the tropical and subtropical streams.

The Chichiawan Stream $\left(24^{\circ} 23^{\prime} \mathrm{N}, 121^{\circ} 18^{\prime} \mathrm{E}\right)$ is a headwater stream of central Taiwan at an elevation of 1,770 to $2,100 \mathrm{~m}$. The tropical/subtropical monsoon climate in Taiwan is characterized by abundant rainfall in the summer and a dry period in the winter ( $\mathrm{Yu}$ and Lin 2009). The stream is characterized by short, straight, and steep channels and is often influenced by fluctuations in precipitation and typhoons. The Chichiawan Stream is the last refuge for the critically endangered Formosan salmon (Oncorhynchus formosanus). Due to the Formosan salmon's critically endangered status (Chung et al. 2008), there is an urgent need to identify the energy sources supporting the stream food web. Lin et al. (2012) identified mayfly grazers as an important food source for the Formosan salmon in the stream. Nevertheless, the diet of mayfly grazers in the Chichiawan Stream is still unclear. Our objectives are (1) to identify algal compositions in the gut contents of two dominant mayfly grazers (families Baetidae and Heptageniidae) in this subtropical mountain stream, (2) to determine whether there is a seasonal variation in the diet of these grazers, and (3) to assess the degree of food selectivity by these grazers by comparing the algal composition of their gut contents with the algal composition of bricks in the stream where grazing by aquatic insects was excluded.

\section{Methods}

\section{Study site}

The Chichiawan Stream $\left(24^{\circ} 23^{\prime} \mathrm{N}, 121^{\circ} 18^{\prime} \mathrm{E}\right)$ is a third-order stream of central Taiwan. The stream is $15.3 \mathrm{~km}$ long with a high mean gradient of $130 \mathrm{~m} \mathrm{~km}^{-1}$ and a catchment area of $76 \mathrm{~km}^{2}$. The upper reach of the Chichiawan Stream is bordered by natural forest. Climatic data derived from a local weather station (Taichung) from 1981 to 2010 (Climatological Data Annual Report, Central Weather Bureau of Taiwan) showed that in the dry season of October to February, the mean monthly rainfall normally does not exceed $40 \mathrm{~mm}$ and in the wet season of May to September, the average monthly rainfall frequently exceeds $300 \mathrm{~mm}$. The mean discharge and current velocity are higher in the wet season than in the dry season (Table 1). The stream bed consists of a high proportion of pebbles in the dry season but is dominated by cobbles and boulders in the wet season (Lin et al. 2006). The mean water temperature ranges from $19^{\circ} \mathrm{C}$ in the wet season to $9^{\circ} \mathrm{C}$ in the dry season. The conductivity values are slightly higher in the dry season than in the wet season. The concentration of dissolved inorganic nitrogen (DIN $=\mathrm{NO}_{3}{ }^{-}+$ $\mathrm{NO}_{2}{ }^{-}+\mathrm{NH}_{4}^{+}$) and total phosphorous (TP) was similar in both seasons.

\section{Sample collection}

Aquatic insects are the dominant herbivores in the Chichiawan Stream. Only a small number of other herbivores, including tadpoles (Bufo bankorensis and Rana sauteri), snails (Hippeutis sp. and Lymnaea sp.), and fish (Varicorhinus barbatulus and Crossostoma lacustre), are normally observed in the stream (Lin et al. 2012). Aquatic insects living in the stream are dominated by algivorous grazers and filter feeders (Kuo and Chiu 2005). Two dominant taxa of grazers (Lin et al. 2012), the Baetidae mayfly (Baetis spp.) and the Heptageniidae mayfly (Rhithrogena ampla), were collected for examination of their gut contents in this study.

Mayfly samples were collected from randomly selected cobbles in riffles of the midstream of the Chichiawan Stream using a hand net, as riffles constituted $>80 \%$ of the stream area (Yeh 2006). To reveal seasonal variations, cobbles with a diameter of approximately $20 \mathrm{~cm}$ were collected during the dry season of January and February and during the wet season of June and early July 2005. Only two cobbles were processed each day of each season because mayflies were collected during their feeding time (during the daytime between 1600 and 1800 hours) to minimize the percentage of empty guts (Yu 2009). The procedure was repeated for 6 days in the dry season and 5 days in the wet season. The sampling was completed before the annual typhoon season (July to October) because the high discharge levels have been shown to remarkably reduce aquatic insect populations (Chiu et al. 2008) and 
Table 1 Physico-chemical variables in the Chichiawan Stream in the dry and wet seasons

\begin{tabular}{llll}
\hline Variables & Dry season & Wet season & Reference \\
\hline Chl a concentration on insect-excluded bricks $\left(\mathrm{mg} \mathrm{m}^{-2}\right)$ & 0.4 to 14.4 & 4.3 to 49.9 & Present study \\
Chl a concentration on grazed cobbles $\left(\mathrm{mg} \mathrm{m}^{-2}\right)$ & 1.9 to 53.5 & 6.1 to 182.7 & Present study \\
Conductivity $\left(\mu \mathrm{S} \mathrm{cm}^{-1}\right)$ & $287.0 \pm 11.0$ & $222.5 \pm 1.5$ & Present study \\
Current velocity $\left(\mathrm{m} \mathrm{s}^{-1}\right)$ & $0.87 \pm 0.10$ & $1.10 \pm 0.05$ & Present study \\
Discharge $\left(\mathrm{m}^{3} \mathrm{~s}^{-1}\right)$ & 1.84 to 2.30 & 2.58 to 2.96 & Chung et al. (2008) \\
Dissolved inorganic nitrogen (DIN, $\left.\mathrm{mg} \mathrm{L}^{-1}\right)$ & $1.81 \pm 1.61$ & $1.57 \pm 0.85$ & Lin et al. (2006) \\
Substrate type & Pebbles $(42 \%)$ & Cobbles $(26 \%)$, boulders (21\%) & Lin et al. (2006) \\
Total phosphorus $\left(\mathrm{TP}, \mathrm{mg} \mathrm{L}^{-1}\right)$ & $0.03 \pm 0.02$ & $0.02 \pm 0.02$ & Lin et al. (2006) \\
Water temperature $\left({ }^{\circ} \mathrm{C}\right)$ & $9.1 \pm 0.4$ & $18.8 \pm 0.8$ & Present study \\
\hline
\end{tabular}

Physico-chemical variables (mean \pm standard deviation, range, or proportion) in the Chichiawan Stream in the dry and wet seasons before the occurrence of typhoons.

algal biomass (Tsai et al. 2014) in the stream. In total, 12 and 10 cobbles were collected during the dry and wet seasons, respectively.

The mayflies living on each cobble were carefully removed with forceps and placed in a squirt bottle filled with $75 \%$ ethanol. Prior to gut removal, the total body length and head capsule width of the mayflies were recorded. The entire gut was removed under a stereomicroscope. The entire gut content was fixed in Lugol's solution for algal taxa identification. After removal of aquatic insects, the epilithic algal samples on the cobbles were also collected for further analyses.

During the two study periods, aquatic insects were excluded from epilithic algae by field caging in the Chichiawan Stream (Figure 1). The size of the cages was $36 \mathrm{~cm}$ in length, $23 \mathrm{~cm}$ in width, and $18 \mathrm{~cm}$ in height and covered with fine nets (mesh $=0.025 \mathrm{~mm}$ ) to exclude insects and falling leaf litter. We put one brick in each cage $(n=10)$ and incubated them in riffles for 40 days prior to the sampling in the stream. The epilithic algal samples were collected after the incubation of the insect-excluded bricks in the field. However, one brick was lost upon retrieval in the wet season. Caging to exclude insects was assessed as the control of potentially available algal community to grazers by comparing the algal abundance and composition found on the bricks with those on the cobbles collected after removal of aquatic insects in riffles.

For collecting epilithic algal samples, a frame made of steel was used to define an algal patch sampling area of $12.5 \mathrm{~cm}^{2}$. Four algal patches were scraped off a surface area on each brick or cobble of $50 \mathrm{~cm}^{2}$ with a toothbrush. The scraped algae were washed off from the toothbrush and the brick or cobble with filtered stream water, and the algae/water mixture was poured into a $100-\mathrm{mL}$ graduated sample bottle. The sample bottles were transferred to a refrigerator on ice and stored in the dark until the samples were processed. In the laboratory, the algal samples were centrifuged for $10 \mathrm{~min}$ to concentrate them to $5 \mathrm{~mL}$. A 3 -
$\mathrm{mL}$ subsample was filtered using a GF/F glass fiber filter (Whatman, GE Healthcare UK Limited, Buckinghamshire, $\mathrm{UK})$, and chlorophyll $a$ ( $\mathrm{Chl} a$ ) was extracted from the filter using a solution of $90 \%$ acetone (Lobban et al. 1988). The other 2-mL subsample was fixed in Lugol's solution for taxa identification.

Epilithic algal compositions were identified and counted using a light microscope of differential interference contrast (Zeiss Axioplan 2, Göttingen, Germany). Filamentous

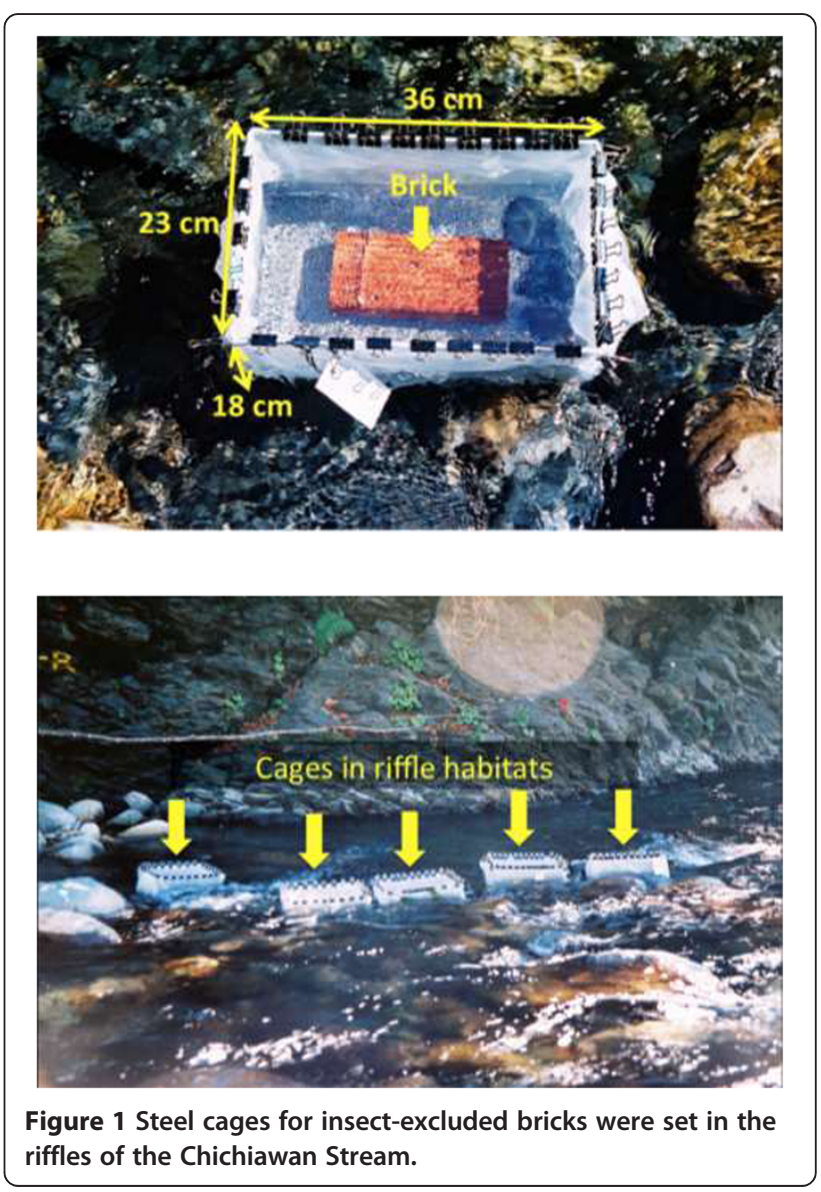


algae such as Oscillatoria and Cladophora were counted in every cell using a hemocytometer. Diatom samples were further treated with $\mathrm{H}_{2} \mathrm{SO}_{4}$ and $\mathrm{KNO}_{3}$ (Sabater et al. 1990) and mounted with Naphrax. At least 500 diatom valves were counted per sample. Identification was carried out according to Patrick and Reimer (1966), Patrick and Reimer (1975), Round et al. (1990), Vyverman (1991), Yamagishi (1992), Round and Bukhtiyarova (1996), and Krammer and Lange-Bertalot (1997). The relative abundance (\%) of algal cells was calculated for analysis of the algal composition.

\section{Data analysis}

A two-tailed Student's $t$ test was used to compare epilithic Chl $a$ concentrations between the insect-excluded bricks and grazed cobbles and to compare head capsule width of mayflies between the wet and dry season. Epilithic algal species were categorized into five physiognomic groups, including adnate, stalked, erect, motile, and filamentous, using a modified version of the methods of Wellnitz and Ward (1998) and Holomuzki and Biggs (2006). To assess seasonal changes in the diets of the mayflies, variations in the algal compositions of their gut contents were examined using multivariate analyses in PRIMER v6 (Clarke and Gorley 2006, PRIMER-E Ltd, Plymouth, UK). Empty guts were excluded from this analysis. Dissimilarity coefficients of untransformed cell numbers of algal communities on the insect-excluded bricks and in the gut contents were computed using Gower's distance, which takes into account the joint absence of food items in the samples. The dissimilarity matrix was first classified by hierarchical agglomerative clustering using the unweighted pair group mean arithmetic (UPGMA) linking method and was then ordinated using the nonmetric multidimensional scaling (MDS) techniques. Using season and mayfly taxon as two grouping variables, we assessed the dispersion of algal composition within each group in ordination space using permutational multivariate analysis of variance (PERMANOVA). A one-way PERMANOVA analysis of Gower's distance was used to determine the seasonal effect on algal compositions of the insect-excluded bricks, and a two-way PERMANOVA was used to determine the interactive effect of season and mayfly taxon on algal compositions in the gut contents and pooled samples of insect-excluded bricks and gut contents. Effects were considered to be significant at the 0.05 probability level by comparing the observed statistic to its 9999 permutations distribution in the absence of differences. In cases of a restricted number of possible permutations in pairwise tests, $p$ values were obtained from Monte Carlo samplings (Anderson and Robinson 2003). Similarity of percentages (SIMPER) was employed to reveal which algal species contributed most to the dissimilarities between the groups for each season or the most common algal species in replicate samples for each group. All the multivariate analyses were performed using the PRIMER v6 with PERMANOVA + add-on software package (Anderson et al. 2008).

We further used Chesson's alpha $(\alpha)$ (Chesson 1978; Alverson and Courtney 2002) to determine algal species preference by comparing the algal species in the gut contents of both mayflies to the relative availability of epilithic algae on the insect-excluded bricks.

$$
\alpha=\left(r_{i} / p_{i}\right) / \Sigma\left(r_{i} / p_{i}\right)
$$

where $r_{i}$ is the relative abundance of algal species $i$ in the gut content and $p_{i}$ is the relative abundance of algal species $i$ in the source sample. The index returns a proportion coefficient from 0 to 1 , with values exceeding $1 / n$ indicating a preference for algal species $i$ and values less than $1 / n$ indicating an avoidance of algal species $i$, where $n$ is the total number of algal species included in the analysis. In this study, only the most 20 common algal species (each contributes $>2 \%$ to the similarity by using the SIMPER analysis) in replicate samples on the insect-excluded bricks were included for the analysis in each season (i.e., $n=20,1 / n=0.05$ ).

\section{Results}

\section{Insect-excluded bricks}

Epilithic Chl $a$ concentrations on the insect-excluded bricks ranged from 0.4 to $14.4 \mathrm{mg} \mathrm{m}^{-2}$ in the dry season and 4.3 to $49.9 \mathrm{mg} \mathrm{m}^{-2}$ in the wet season in the Chichiawan Stream (Table 1). Diatoms were the most abundant taxa of the algal communities on the insect-excluded bricks. Of the 58 taxa identified, 52 taxa were diatoms, followed by cyanobacteria and green algae (Additional file 1). Diatoms contributed $85 \%$ of the total cell numbers in the algal communities. Achnanthes spp., Achnanthidium pyrenaicum (Hustedt) H. Kobayasi, Achnanthidium minutissimum (Kützing) Czarnecki, Cocconeis placentula var. euglypta (Ehrenberg) Grunow, Gomphonema spp., and Planothidium lanceolatum (Brébisson ex Kützing) LangeBertalot were the most abundant species. Algal compositions on the bricks in the dry season differed significantly from the wet season (Figure 2, Table 2). Achnanthes spp. were the most abundant diatom species in the dry and wet seasons (Figure 3a).

Seasonal variations in the algal composition were further determined using the SIMPER analysis (Figure 3b). Approximately, $11 \%$ of the variations between the dry and wet seasons were caused by Cocconeis placentula var. euglypta, which was more abundant during the wet season. A. pyrenaicum (10.6\%) and Gomphonema spp. (9.6\%) were also significant contributors to the variation and were also more abundant during the wet season. 


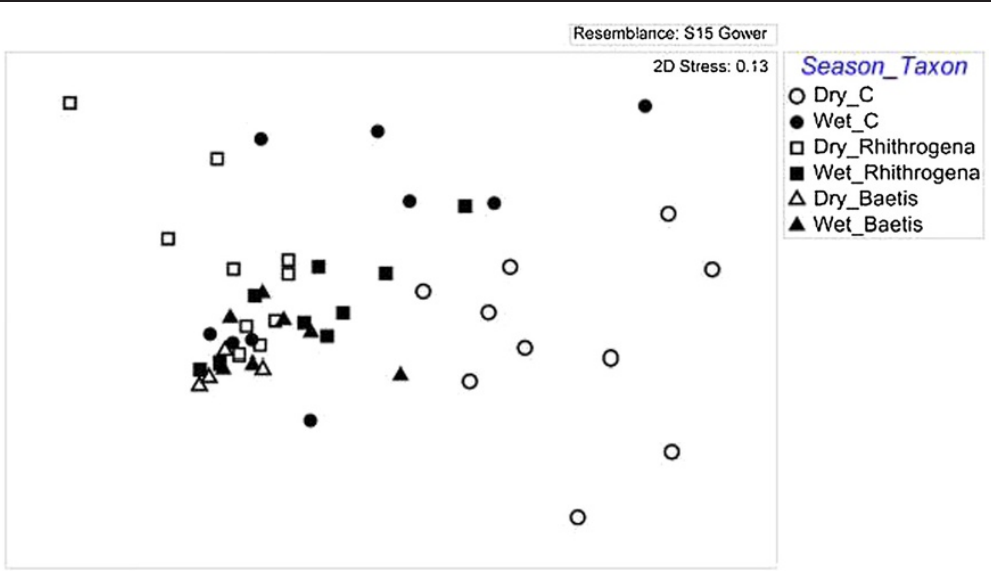

Figure 2 Results of the MDS analysis. On the epilithic algal compositions in the gut contents of the two mayflies (Baetis and Rhithrogena) and on the insect-excluded bricks (C) in the wet and dry seasons in the Chichiawan Stream.

\section{Comparison of caged bricks with grazed cobbles}

Epilithic Chl $a$ concentrations on the insect-excluded or caged bricks incubated for 40 days were lower but comparable to those on the grazed cobbles after removal of aquatic insects in riffles of the Chichiawan Stream (Table 1, Student's $t$ test, $p=0.013$ for the dry season and $p=0.075$ for the wet season). Communities of epilithic algae on the caged bricks and grazed cobbles were dominated by stalked or adnate form of diatoms both in the dry and wet seasons. Using the SIMPER analysis, the

Table 2 Results of the multivariate permutational analysis

\begin{tabular}{llllll}
\hline Samples & df & SS & MS & Pseudo-F & $\boldsymbol{p}$ (perm) \\
\hline Insect-excluded bricks & & & & & \\
Season & 1 & 2,046 & $2,046.1$ & 6.775 & $\mathbf{0 . 0 0 0 5}$ \\
Residuals & 17 & 5,134 & 302.0 & & \\
Total & 18 & 7,180 & & & \\
Gut contents of mayflies & & & & & \\
Season & 1 & 1,198 & $1,198.4$ & 3.995 & $\mathbf{0 . 0 0 7 8}$ \\
Treatment & 1 & 873 & 873.3 & 2.911 & $\mathbf{0 . 0 3 0 9}$ \\
Season $\times$ Treatment & 1 & 318 & 318.3 & 1.061 & 0.3698 \\
Residuals & 25 & 7,500 & 300 & & \\
Total & 28 & 10,443 & & & \\
Insect-excluded bricks + & & & & & \\
gut contents of mayflies & & & & & \\
Season & 1 & 389 & 388.7 & 2.810 & $\mathbf{0 . 0 1 4 1}$ \\
Treatment & 2 & 2,753 & $1,376.4$ & 9.948 & $\mathbf{0 . 0 0 0 1}$ \\
Season $\times$ treatment & 2 & 1,447 & 723.3 & 5.228 & $\mathbf{0 . 0 0 0 1}$ \\
Residuals & 43 & 5,949 & 138.4 & & \\
Total & 48 & 10,816 & & & \\
\hline Resuts of the muttvaite & & &
\end{tabular}

Results of the multivariate permutational analysis (PERMANOVA) of effects of season and treatment (mayfly taxon or insect-exclusion) on the algal communities in the Chichiawan Stream. $p$ (perm), possible permutations. Statistically significant $p$ values $(<0.05)$ are highlighted in bold font. community structures of epilithic algae on the caged bricks and grazed cobbles were slightly different (Table 3 ). The algal composition responded to seasonal variation more than the variation caused by grazing. Achnanthes spp. and Planothidium lanceolatum were frequently observed on the caged bricks and grazed cobbles both in the dry and wet seasons. However, A. pyrenaicum and Gomphonema spp. occurred more frequently in the wet season. While Cocconeis placentula and Diatoma vulgaris occurred more frequently on the grazed cobbles in the dry season, Achnanthidium minutissimus was more frequently observed on the caged bricks in the wet season. It appears that algal composition on the grazed cobbles can be approximated by the composition found on the caged bricks; therefore, caging to exclude insects was used as a grazer-excluded control of algal composition.

\section{Gut contents of mayflies}

In total, 11 and 19 individuals of Baetis and Rhithrogena were examined for their gut contents and their head capsule widths (mean \pm standard deviation) were $0.99 \pm$ 0.19 and $2.74 \pm 0.67 \mathrm{~mm}$, respectively. No significant difference in head capsule width was detected between the wet and dry seasons for both mayflies (Student's $t$ test, $p=0.84$ for Baetis and $p=0.96$ for Rhithrogena). However, the algal composition of the gut contents of both mayflies between the two seasons was significantly distinct (Table 2). Algal compositions between the gut contents of two mayflies also significantly differed. The composition of the gut contents of Rhithrogena was more variable than that of Baetis (Figure 2).

The seasonal differences in the preference of diatom species by Baetis and Rhithrogena, assessed using Chesson's $\alpha$, were apparent between the dry and wet seasons. Both Baetis and Rhithrogena preferred adnate diatoms, Achnanthes spp. and Achnanthidium pyrenaicum, in the dry and wet 


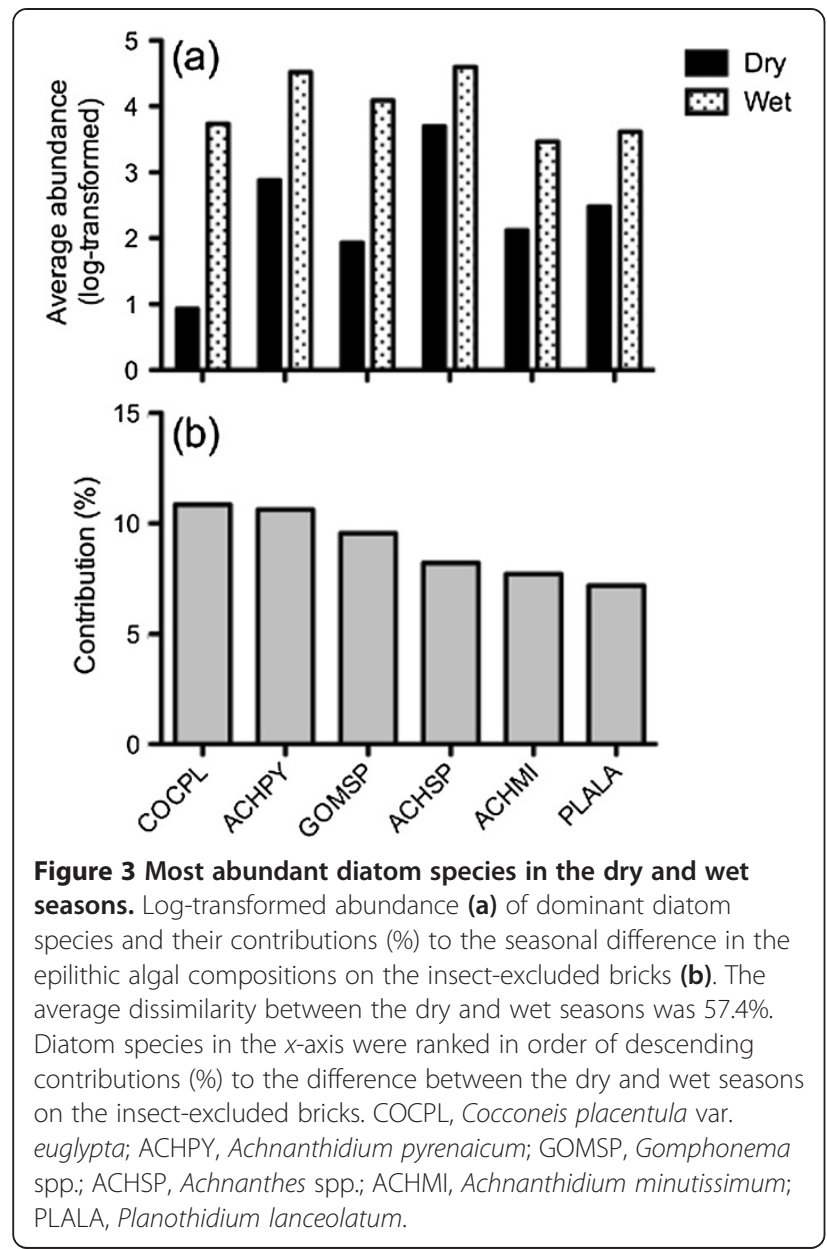

Table 3 SIMPER analysis of contribution of species

\begin{tabular}{|c|c|c|c|c|}
\hline \multirow[t]{2}{*}{ Algal species } & \multicolumn{2}{|c|}{ Dry season } & \multicolumn{2}{|c|}{ Wet season } \\
\hline & Caged & Grazed & Caged & Grazed \\
\hline Achnanthes spp. & 35.50 & 51.87 & 2.67 & 2.26 \\
\hline $\begin{array}{l}\text { Achnanthidium minutissimum } \\
\text { (Kützing) Czarnecki }\end{array}$ & 13.13 & 5.49 & 2.74 & \\
\hline $\begin{array}{l}\text { Achnanthidium pyrenaicum } \\
\text { (Hustedt) H. Kobayasi }\end{array}$ & & & 55.04 & 71.74 \\
\hline Cocconeis placentula var. euglypta & & 7.77 & 2.26 & 7.19 \\
\hline $\begin{array}{l}\text { Diatoma vulgaris Bory de } \\
\text { Saint-Vincent }\end{array}$ & & 2.79 & & \\
\hline Gomphonema spp. & & & 18.53 & 13.19 \\
\hline $\begin{array}{l}\text { Planothidium lanceolatum } \\
\text { (Brébisson ex Kützing) } \\
\text { Lange-Bertalot }\end{array}$ & 41.48 & 24.08 & 5.31 & 2.58 \\
\hline Total contribution & 90.11 & 92.00 & 86.55 & 96.96 \\
\hline
\end{tabular}

SIMPER (similarity of percentage) analysis of contribution (\%) of species occurrence in epilithic algal community respectively sampled on the caged bricks and the grazed cobbles in the dry and wet seasons in the Chichiawan Stream. seasons (Figure 4). The stalked diatoms, Gomphonema spp., were preferred by Baetis, but not by Rhithrogena, in the dry season (Figure 4a). In the wet season, two mayflies preferred similar species of adnate diatoms with the exception of A. minutissimum, which was also preferred only by Baetis (Figure $4 \mathrm{~b}$ ).

\section{Pooled analysis of insect-excluded bricks and gut contents of mayflies}

When analyzing pooled algal compositions on the insectexcluded bricks and in the gut contents of both mayflies, the interactive effects of season and mayfly taxon on algal communities were significant (Table 2). The results of pairwise tests further showed that the algal compositions on the insect-excluded bricks (as a grazer-excluded control) coincided with the gut contents in the wet season (Table 4). In the dry season, however, the algal composition of the gut contents and on the insect-excluded bricks was highly variable and showed a widespread in the MDS ordination (Figure 2). The algal composition of the gut contents of Baetis and Rhithrogena was distinct from that of insect-excluded bricks in the dry season. Furthermore, the algal composition of the gut contents of Rhithrogena

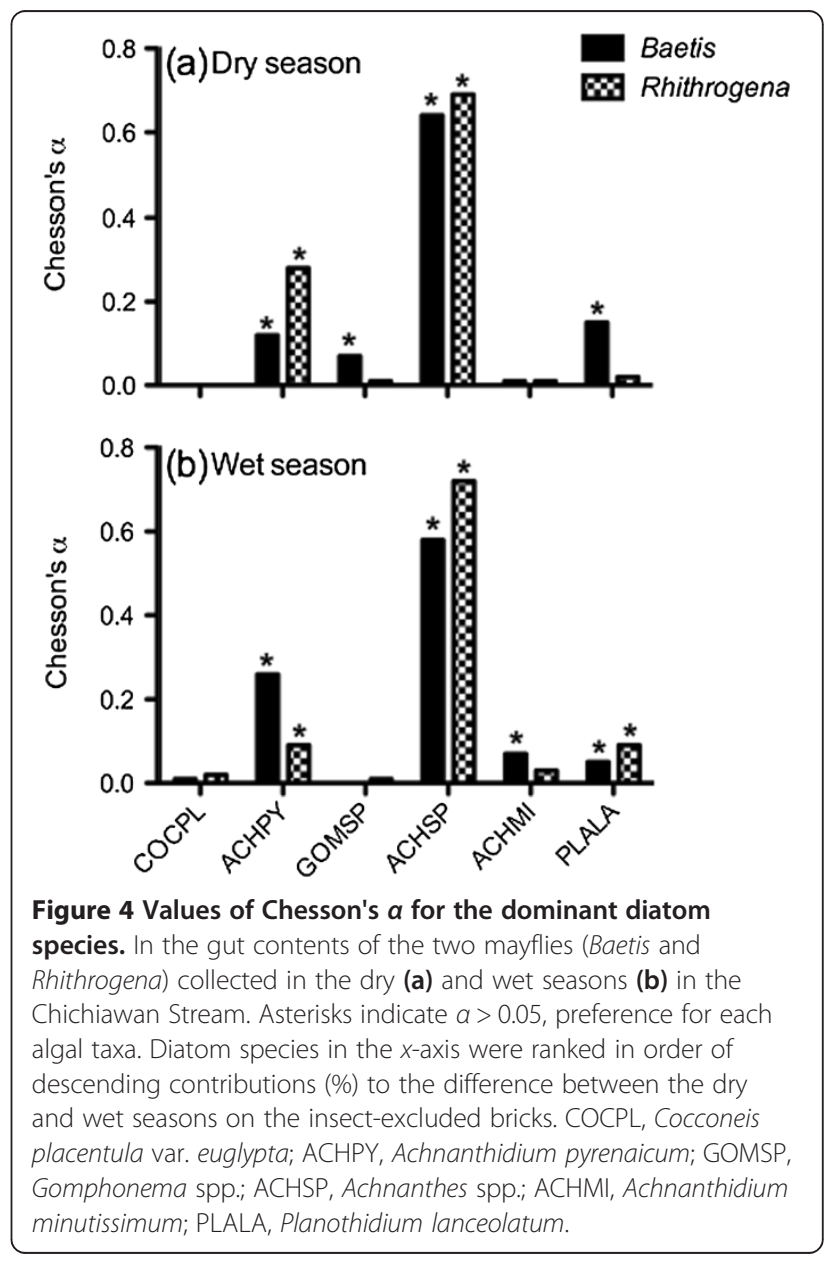


Table 4 Pair-wise tests of the effects of season and treatment

\begin{tabular}{llll}
\hline Groups & $\boldsymbol{t}$ & $\boldsymbol{p}$ (perm) & $\boldsymbol{p}$ (MC) \\
\hline Groups within level 'wet season' & & & \\
Rhithrogena vs. Baetis & 1.086 & 0.3071 & 0.2986 \\
Rhithrogena vs. control & 1.246 & 0.1740 & 0.1936 \\
Baetis vs. control & 1.473 & 0.0911 & 0.1083 \\
Groups within level 'dry season' & & & \\
Rhithrogena vs. Baetis & 1.960 & $\mathbf{0 . 0 2 4 6}$ & $\mathbf{0 . 0 3 0 7}$ \\
Rhithrogena vs. control & 4.263 & $\mathbf{0 . 0 0 0 1}$ & $\mathbf{0 . 0 0 0 1}$ \\
Baetis vs. control & 3.663 & $\mathbf{0 . 0 0 0 8}$ & $\mathbf{0 . 0 0 0 1}$ \\
Groups within level 'treatment' & & & \\
Dry vs. wet (Rhithrogena) & 2.070 & $\mathbf{0 . 0 0 0 6}$ & $\mathbf{0 . 0 0 6 6}$ \\
Dry vs. wet (Baetis) & 1.401 & 0.1323 & 0.1509 \\
Dry vs. wet (control) & 2.589 & $\mathbf{0 . 0 0 0 5}$ & $\mathbf{0 . 0 0 0 5}$ \\
\hline Par-wse
\end{tabular}

Pair-wise tests of the effects of season and treatment (mayfly taxon or insect-exclusion) on the algal communities on the insect-excluded bricks (control) and in the gut contents of the two mayflies (Baetis and Rhithrogena). $p$ (perm), possible permutations. $p(\mathrm{MC})$, Monte Carlo $p$ values. Statistically significant $p$ values $(<0.05)$ are highlighted in bold font.

significantly differed from that of Baetis in the dry season (Table 4). The algal compositions of the gut contents of Rhithrogena and on the insect-excluded bricks in the dry season were distinct from those in the wet season. However, the algal composition of the gut contents of Baetis was similar between both seasons.

\section{Discussion}

\section{Gut contents of mayflies}

In temperate streams, while Baetis was categorized as collectors-gatherers and facultative scrapers, Rhithrogena was assigned as scrapers and facultative collectorsgatherers (Merritt et al. 2008). Such classifications were mainly based on examination of the mouthpart structure and foraging behavior for mayflies, rather than on the gut contents. Consequently, both mayflies in different taxa were considered to feed on the same food sources: detritus and diatoms (Merritt et al. 2008). Our results of gut content analysis demonstrate that both mayflies preferred understory and small adnate diatoms, Achnanthes spp. and A. pyrenaicum in the Chichiawan Stream. We also discovered that the preference of diatom species by Baetis and Rhithrogena was different; stalked diatoms Gomphonema spp. were preferred by Baetis, but not by Rhithrogena, in the dry season. In the wet season, however, when the current velocity became relatively faster, the distinctness in preference by Baetis and Rhithrogena decreased.

In the dry season, diatoms in the gut contents of Baetis and Rhithrogena show some distinctness, except for the most dominant Achnanthidium/Achnanthes-type diatoms. Interestingly, only 8 species of 52 taxa of diatoms in this study were dominant in the gut contents, and they were mainly small diatoms. These small cells are monoraphid heterovalves, except the stalked Gomphonema (asymmetrical biraphid). Baetis preferred the stalked Gomphonema, but not Rhithrogena. Different types of grazers occupied different feeding niches in relation to the key growth forms in the benthic algal mat (Steinman 1996). Scraping and gathering grazers feed on stalked or short filament algal species (e.g., genus Gomphonema) and tend to feed on the mid-layers of algal communities. Rasping and scraping grazers feed on prostrate and adnate algal species such as genus Cocconeis and small Achnanthidium/Achnanthes species. In general, the biovolume of Gomphonema was greater than that of small Achnanthidium/Achnanthes-type diatoms. The preference for Gomphonema by Baetis in the dry season might not be caused by the size or characteristics of the mouthpart but instead be a result of the hydrological condition in the stream. Baetis has a fusiform body and prefers a near-bed current velocity of $<80 \mathrm{~cm} \mathrm{~s}^{-1}$, whereas Rhithrogena has a flattened body and prefers a current velocity of $>80 \mathrm{~cm} \mathrm{~s}^{-1}$ (S. F. Yu, personal observation). High velocity scoured off the stalked or large-sized algae, especially the overstory and mid-layer algal species. Therefore, Baetis had more opportunity to feed on larger diatom species than Rhithrogena. A similar study conducted in northeastern Taiwan also indicated that Rhithrogena preferred riffles with faster current velocity, though not so fast as that in the Chichiawan Stream (Yang 2012).

\section{Seasonal variation in algal composition}

The difference in diatom composition on the insectexcluded bricks in the Chichiawan Stream between the dry and wet seasons was contributed mostly from genera Cocconeis, which adnates to the understory of algal mat or to the surface of filamentous algae and was more abundant in the wet season. However, such diatoms were not the preferred species for the dominant mayfly grazers in the stream. Two possible explanations must be considered for why Rhithrogena and Baetis did not prefer Cocconeis spp. in the stream. First, genus Cocconeis was attached directly via the raphid valve by mucilage, but Achnanthidium and Achnanthes were attached to rock using a mucilage stalk secreted from the end of the raphid valve. Therefore, the short-stalked Achnanthidium and Achnanthes were relatively easier for mayfly to graze than the prostrate and tightly attached Cocconeis. The second reason might be that Cocconeis usually attach tightly to the surface of filamentous green algae, such as Cladophora and Spirogyra. However, filamentous algae are usually difficult for grazing insects to harvest or digest (Lamberti and Resh 1983). Overgrowth of the filaments of Cladophora interfered with the feeding of Rhithrogena that requires a relatively flat substrate free of obstructions to the movements of the 
maxillary palps (McShaffrey and McCafferty 1988). Moreover, small and stalked Achnanthidium/Achnanthes-type diatoms with monoraphid were always attaching to the rocks in the rapid riffles with less filamentous algae, and they became the most important food source for Baetis and Rhithrogena in the stream.

Regardless of dry or wet season or changing flow regime, the two mayfly grazers preferred small adnate diatoms species in the Chichiawan Stream. The Chesson's $\alpha$ values were much higher for adnate diatoms, Achnanthes spp. and A. pyrenaicum, than the values for the other species, indicating that they were the most preferred diatom species for mayfly grazers, Baetis and Rhithrogena, in both seasons. These small adnate diatom species were also the most abundant algal species in the Chichiawan Stream (Yu and Lin 2009) and were usually found in riffles with high current velocity (Su et al. 2009).

\section{Food selectivity by mayflies}

The algal grazer Baetidae was observed using its gougeshaped mandibular tips (Arens 1990). Stalked, erect, and filamentous growth forms of algae are often vulnerable to most herbivores, whereas prostrate forms are vulnerable only to raspers and scrapers (Holomuzki et al. 2010). Wellnitz and Ward (1998) indicated that adnate forms of algae such as Achnanthes are most vulnerable to the gouging mouthparts of Baetid mayflies. Nearly all mayflies of the family Heptageniidae can use their two-segmented strongly modified labial palps, with scrubbing brushes similar to maxillary palps, as algal scrapers (Arens 1990). These might be the reasons that understory algae rather than overstory algae were preferred by the dominant mayfly grazers in the Chichiawan Stream.

Our findings are contrary to the general impression that overstory algae are more vulnerable than understory algae to grazing insects. Steinman (1996) indicated that 37 out of 43 previous studies (or 86\%) show that grazers in streams have a preference for overstory diatoms. However, these studies usually focus on the functional feeding group of gathering-collector. Relatively little attention has been paid to the feeding behavior and the gut content of Heptageniid Rhithrogena species with a scraping brush on the maxillary palp (e.g., McShaffrey and McCafferty 1988). Wellnitz and Ward (1998) reported that a grazer, Ecdyonurus venosus (Heptageniidae), uses a brushing mouthpart and other grazers, Baetis spp. (Baetidae), use mandibles and maxilla to scrape and gather periphyton. Research on the gut contents of Baetis and Rhithrogena in tropical and subtropical streams is still rare (Yang 2012). Our results demonstrate that Baetis and Rhithrogena preferentially feed on understory algae, which were mainly adnate form or Achnanthes-type algae, in the Chichiawan Stream.

The preference of small adnate diatoms species by the dominant mayfly grazers in the Chichiawan Stream year- round is most likely a result of the high current velocity on algal physiognomy in the stream. The current velocity of the stream is the main factor affecting epilithic algal biomass and compositions in this subtropical mountain stream (Tsai et al. 2014), which can regulate the levels of subsidy and stress experienced by periphyton by simultaneously regulating nutrient uptake rates and shear forces (Biggs et al. 1998). Continental islands in the tropics/ subtropics of the western Pacific are characterized by mountainous watersheds, high precipitation, and high water runoff; therefore, many mountain streams on these islands, including the Chichiawan Stream, have relatively short, straight, and steep channels in comparatively small and narrow watersheds (Smith et al. 2003). The current velocity in the Chichiawan Stream remained fast $\left(>0.60 \mathrm{~m} \mathrm{~s}^{-1}\right)$ year-round. The high gradient $\left(130 \mathrm{~m} \mathrm{~km}^{-1}\right.$ ) and flow environments in the stream caused the diatom communities to shift toward more adnate forms in the stream, such as the tightly adherent diatoms Achnanthes, Achnanthidium, and Cocconeis. Our results suggest that the preference by mayfly grazers in the stream is potentially influenced by algal availability.

Although a previous study found that the density of Achnanthidium species decreased with increasing grazer density (Yu and Lin 2009), mayflies did not actually prefer the similar adnate form of $A$. minutissimum, which were the smallest-sized diatoms in the Achnanthidium species complex in the Chichiawan stream. A. minutissimum can colonize rapidly in this stream after flushing floods (Lin and Lin 2009). Grazers can maintain the early successional nature of algal communities under conditions of high current velocity (Poff and Ward 1995). Small-celled unicellular algae have a low biomass, short cell cycle, and rapid growth rate. Such conditions favor organisms that follow an opportunistic or r-selection strategy (Sigee 2005). Therefore, while Achnanthes spp. and other Achnanthidium species were preferentially grazed by the dominant mayflies, the smallsized A. minutissimum can grow on the lowest layer of algal mats.

\section{Conclusions}

The two dominant mayfly grazers preferred understory and small adnate diatoms species in the Chichiawan Stream in the dry and wet seasons. The algal physiognomy was most likely attributed to the impact of the high current velocity in the stream. The preference by the mayfly grazers in the stream is potentially influenced by algal availability.

\section{Additional file}

Additional file 1: Algal taxa list. 


\section{Competing interests}

The authors declare that they have no competing interests.

\section{Authors' contributions}

YLC and HJL wrote the manuscript. YLC, SFY, and HJL carried out the data analysis. SFY carried out the sample collection and field studies. All authors read and approved the final manuscript.

\section{Acknowledgements}

This study was financially supported by the Shei-Pa National Park Headquarters, Miaoli County, Taiwan.

\section{Author details}

${ }^{1}$ Department of Life Sciences and Research Center for Global Change Biology, National Chung Hsing University, Taichung 40227, Taiwan. ${ }^{2}$ Shei-Pa National Park, Conservation and Research Section, Miaoli County 36443, Taiwan.

\section{Received: 10 April 2014 Accepted: 13 August 2014}

Published: 2 September 2014

\section{References}

Alverson AJ, Courtney GW (2002) Temporal patterns of diatom ingestion by larval netwinged midges (Diptera: Blephariceridae: Blepharicera). Freshwater Biol 47:2087-2097

Anderson MJ, Robison J (2003) Generalized discriminant analysis based on distances. Aust NZ J Stat 45:301-318

Anderson MJ, Gorley RN, Clarke KR (2008) PERMANOVA + for PRIMER: guide to software and statistical methods. PRIMER-E Ltd., Plymouth, UK

Arens W (1990) Wear and tear of mouthparts: a critical problem in stream animals feeding on epilithic algae. Can J Zoolog 68:1896-1914

Barbee NC (2005) Grazing insects reduce algal biomass in a neotropical stream. Hydrobiologia 532:153-165

Biggs BJF, Goring DG, Nikora VI (1998) Subsidy and stress responses of stream periphyton to gradients in water velocity as a function of community growth form. J Phycol 34:598-607

Boyero L, Ramírez A, Dudgeon D, Pearson RG (2009) Are tropical streams really different? J N Am Benthol Soc 28:397-403

Brito EF, Moulton TP, De Souza ML, Bunn SE (2006) Stable isotope analysis indicates microalgae as the predominant food source of fauna in a coastal forest stream, south-east Brazil. Austral Ecol 31:623-633

Chesson J (1978) Measuring preference in selective predation. Ecology 59:211-215

Chiu MC, Kuo MH, Sun YH, Hong SY, Kuo HC (2008) Effects of flooding on avian top-predators and their invertebrate prey in a monsoonal Taiwan stream. Freshwater Biol 53:1335-1344

Chung LC, Lin HJ, Yo SP, Tzeng CS, Yeh CH, Yang CH (2008) Relationship between the Formosan landlocked salmon Oncorhynchus masou formosanus population and the physical substrate of its habitat after partial dam removal from the Kaoshan Stream, Taiwan. Zool Stud 47:25-36

Clarke KR, Gorley RN (2006) PRIMER v6 User Manual / Tetorial. PRIMER-E Ltd, Plymouth, UK

Feminella JW, Hawkins CP (1995) Interactions between stream herbivores and periphyton: a quantitative analysis of past experiments. J N Am Benthol Soc 14:465-509

Feminella JW, Resh VH (1991) Herbivorous caddisflies, macroalgae, and epilithic microalgae: dynamic interactions in a stream grazing system. Oecologia 87:247-256

Hill WR, Knight AW (1987) Experimental analysis of the grazing interaction between a mayfly and stream algae. Ecology 68:1955-1965

Holomuzki JR, Biggs BJF (2006) Food limitation affects algivory and grazer performance for New Zealand stream macroinvertebrates. Hydrobiologia 561:83-94

Holomuzki JR, Feminella JW, Power ME (2010) Biotic interactions in freshwater benthic habitats. J N Am Benthol Soc 29:220-244

Kohler SL (1984) Search mechanism of a steam grazer in patchy environments: the role of food abundance. Oecologia 62:209-218

Krammer K, Lange-Bertalot H (1997) Bacillariophyceae. Spektrum Akademischer Verlag Heidelberg Press, Berlin

Kuo MH, Chiu MC (2005) Community structure of aquatic insects monitoring in streams of Wuling area., Final report to Shei-Pa National Park (in Chinese)
Lamberti GA, Resh VH (1983) Stream periphyton and insect herbivores: an experimental study of grazing by a caddisfly population. Ecology 64:1124-1135

Lamberti GA, Ashkenas LR, Gregory SV, Steinman AD (1987) Effects of three herbivores on periphyton communities in laboratory streams. J N Am Benthol Soc 6:92-104

Lau DCP, Leung KMY, Dudgeon D (2008) Experimental dietary manipulations for determining the relative importance of allochthonous and autochthonous food resources in tropical streams. Freshwater Biol 53:139-147

Lau DCP, Leung KMY, Dudgeon D (2009) Are autochthonous foods more important than allochthonous resources to benthic consumers in tropical headwater streams? J N Am Benthol Soc 28:426-439

Li AOY, Dudgeon D (2008) Food resources of shredders and other benthic macroinvertebrates across a range of shading conditions in tropical Hong Kong streams. Freshwater Biol 53:2011-2025

Lin ZC, Lin HJ (2009) Colonization of epilithic algae in the Cijiawan Stream of the Wuling area. J Natl Park 21:1-8 (in Chinese)

Lin HJ, Yeh CH, Kuan WH, Peng TR, Tzeng CS, Yang JT, Yeh WB, Yeh CH, Tasi ST (2006) Long-term ecological monitoring and ecosystem modeling in the Wuling area. Technical report. Shei-Pa National Park Administration, Taichung (in Chinese)

Lin HJ, Peng TP, Cheng IC, Chen LW, Kuo MH, Tzeng CS (2012) Trophic model of the subtropical headwater stream habitat of Formosan landlocked salmon Oncorhynchus formosanus. Aquat Biol 17:269-283

Lobban CS, Chapman DJ, Kemer BP (1988) Experimental phycology: a laboratory manual. Cambridge University Press, USA

Mantel SK, Salas M, Dudgeon D (2004) Food web structure in a tropical Asian forest stream. J N Am Benthol Soc 23:728-755

March JG, Pringle CM (2003) Food web structure and basal resource utilization along a tropical island stream continuum, Puerto Rico. Biotropica 35:84-93

McShaffrey D, McCafferty WP (1988) Feeding behavior of Rhithrogena pellucida (Ephemeroptera: Heptageniidae). J N Am Benthol Soc 7:87-99

Merritt RW, Cummins KW, Berg MB (2008) An introduction to the aquatic insects of North America, 4th edn. Kendall/Hunt Publishing Co., Dubuque, lowa

Patrick R, Reimer CW (1966) The diatoms of the United States (vol. 1) Monographs. Academy of National Sciences Press, Philadelphia

Patrick R, Reimer CW (1975) The diatoms of the United States. Monographs, vol 2. Academy of National Sciences Press, Philadelphia

Peterson CG, Vormittag KA, Valett HM (1998) Ingestion and digestion of epilithic algae by larval insects in a heavily grazed montane stream. Freshwater Biol 40:607-623

Poff NL, Ward JV (1995) Herbivory under different flow regimes: a field experiment and test of a model with a benthic stream insect. Oikos 71:179-188

Round FE, Bukhtiyarova L (1996) Four new genera based on Achnanthes (Achnanthidium) together with a re-definition of Achnanthidium. Diatom Res 11:345-361

Round FE, Crawford RM, Mann DG (1990) The diatoms: biology and morphology of the genera. Cambridge University Press, UK

Sabater S, Tomas X, Cambra J, Lange-Bertalot H (1990) Diatom flora of the Cape of Creus Peninsula Catalonia, N.E. of Spain. Nova Hedwigia 5:165-195

Salas M, Dudgeon D (2001) Stable-isotope determination of mayfly (Insecta: Ephemeroptera) food sources in three tropical Asian streams. Arch Hydrobiol $151: 17-32$

Sigee DC (2005) Freshwater microbiology: biodiversity and dynamic interactions of microorganisms in the aquatic environment. John Wiley and Sons Ltd, UK

Smith GC, Covich AP, Brasher AMD (2003) An ecological perspective on the biodiversity of tropical island streams. Bioscience 53:1048-1051

Steinman AD (1996) Effects of grazers on freshwater Benthic algae. In: Stevenson RJ, Bothwell ML, Lowe RL (eds) Algae ecology: freshwater benthic ecosystems. Academic, California

Su MR, Chang ST, Lin HJ (2009) Winter community structure of epilithic diatoms in pools, runs, and riffles of Yousheng Stream during low flow period in Shei-Pa National Park. J Natl Park 19:73-86 (in Chinese)

Tall L, Cattaneo A, Cloutier L, Dray S, Legendre P (2006) Resource partitioning in a grazer guild feeding on a multilayer diatom mat. J N Am Benthol Soc 25:800-810

Tsai JW, Chuang YL, Wu ZY, Kuo MH, Lin HJ (2014) The effects of storm-induced events on the seasonal dynamics of epilithic algal biomass in subtropical mountain streams. Mar Freshwater Res 65:25-38

Vyverman W (1991) Diatoms from Papua New Guinea. Bibliotheca Diatomologica 22. Gebrüder Borntraeger Verlag, Berlin

Wallace JB, Gurtz ME (1986) Response of Baetis mayflies (Ephemeroptera) to catchment logging. Am Midl Nat 115:25-41 
Wellnitz TA, Ward JV (1998) Does light intensity modify the effect mayfly grazers have on periphyton. Freshwater Biol 39:135-149

Yam RSW, Dudgeon D (2005) Stable isotope investigation of food use by Caridina spp. (Decapoda: Atyidae) in Hong Kong streams. J N Am Benthol Soc 24:68-81

Yamagishi T (1992) Plankton algae in Taiwan (Formosa). Uchida Rokakuho Press, Tokyo

Yang TC (2012) The food habits and mouthpart morphology of Heptageniidae in Fu-Shan area. Master thesis. Providence University, Taichun, Taiwan (in Chinese)

Yeh CH (2006) Long-term ecological monitoring and ecosystem modeling in the Wuling area-the study of stream morphology and physical habitat change on the environmental factors.. Technical report to Shei-Pa National Park (in Chinese)

Yu SF (2009) Effects of aquatic insect larvae on epilithic algae in the Wuling erea. Ph.D. Dissertation. National Chung Hsing University, Taichung, Taiwan (in Chinese)

Yu SF, Lin HJ (2009) Effects of agriculture on the abundance and community structure of epilithic algae in mountain streams of subtropical Taiwan. Bot Stud 50:73-87

doi:10.1186/s40555-014-0054-y

Cite this article as: Chuang et al.: Dietary variation and food selection by mayfly grazers in a subtropical mountain stream. Zoological Studies 2014 53:54

\section{Submit your manuscript to a SpringerOpen ${ }^{\circ}$ journal and benefit from:}

- Convenient online submission

- Rigorous peer review

- Immediate publication on acceptance

- Open access: articles freely available online

- High visibility within the field

- Retaining the copyright to your article 